\title{
In vitro sensitivity of Fusarium graminearum isolates to fungicides
}

\author{
Aveline Avozani ${ }^{1}$; Rosane Baldiga Tonin ${ }^{1}$; Erlei Melo Reis ${ }^{1,2}$; Juliane Camera ${ }^{1}$; Camila Ranzi ${ }^{1}$
}

${ }^{1}$ Faculdade de Agronomia e Medicina Veterinária, Laboratório de Fitopatologia-Micologia, Universidade de Passo Fundo - UPF, 99001, Passo Fundo, RS, Brasil. ${ }^{2}$ Professor da FAMV/PPGAgro/UPF, pesquisador CNPq.

Autor para correspondência: Aveline Avozani (avelinebio3@yahoo.com.br)

Data de chegada: 08/05/2013. Aceito para publicação em: 28/05/2014.

$10.1590 / 0100-5405 / 1891$

\section{ABSTRACT}

Avozani, A.; Tonin, R.B.; Reis, E.M.; Camera, J.; Ranzi, C. In vitro sensitivity of Fusarium graminearum isolates to fungicides. Summa Phytopathologica, v.40, n.3, p.231-247, 2014.

Head blight of wheat is a disease of global importance. In Brazil, it can cause damage of up to $27 \%$. As resistant cultivars are not available yet, shortterm disease control relies on the use of fungicides. The first step to reach effective management is to identify potent fungicides. In vitro experiments were conducted to determine the inhibitory concentration $50 \%\left(\mathrm{IC}_{50}\right)$ for mycelial growth or conidial germination, according to the chemical group of fungicides, of five Fusarium graminearum isolates of different origins. The following demethylation inhibitor (DMI) fungicides were tested: epoxiconazole, cyproconazole, metconazole, prochloraz, protioconazole and tebuconazole. In addition, azoxystrobin, kresoxim-methyl, pyraclostrobin and trifloxystrobin were included in the study, representing Quinone outside inhibitor fungicides (QoI), as well as a tubulin synthesis inhibitor, carbendazim and two ready mixtures, trifloxystrobin + tebuconazole or trifloxistrobin + prothioconazole. DMI's showed lower $\mathrm{IC}_{50}$ values compared to the QoI's. For the five tested isolates, in the overall mean, $\mathrm{IC}_{50}$ considering mycelial growth ranged for DMI's from $0.01 \mathrm{mg} / \mathrm{L}$ (metconazole, prochloraz and prothioconazole) to $0.12 \mathrm{mg} / \mathrm{L}$ (cyproconazole) and considering conidial germination for Qol's from $0.21 \mathrm{mg} / \mathrm{L}$ (azoxystrobin) to $1.33 \mathrm{mg} / \mathrm{L}$ (trifloxystrobin). The $\mathrm{IC}_{50}$ for carbendazim was $0.07 \mathrm{mg} / \mathrm{L}$. All tested isolates can be considered sensitive to the studied DMI's, although certain differences in sensitivity could be detected between the isolates originating from one same state.

Additional keywords: Fungitoxicity, Fusarium graminearum, head blight, $\mathrm{IC}_{50}$, sensitivity, Triticum aestivum.

\section{RESUMO}

Avozani, A.; Tonin, R.B.; Reis, E.M.; Camera, J.; Ranzi, C. Sensibilidade in vitro de isolados de Fusarium graminearum a fungicidas. Summa Phytopathologica, v.40, n.3, p.231-247, 2014.

A giberela do trigo é uma doença de importância global. No Brasil, a doença pode causar danos de até $27 \%$. Como cultivares resistentes ainda não estão disponíves, o controle da doença num curto espaço de tempo, fundamenta-se no uso de fungicidas. O primeiro passo para alcançar manejo eficiente é a identificação de fungicidas potentes. Em experimentos in vitro, determinouse a concentração inibitória de $50 \%\left(\mathrm{CI}_{50}\right)$ para o crescimento miceliano ou para germinação de conídios em função do grupo químico dos fungicidas de cinco isolados de Fusarium graminearum de diferentes origens. Os fungicidas inibidores da desmetilação (IDM) testados foram: epoxiconazol, cyproconazol, metconazol, procloraz, protioconazol e tebuconazol. Em adição, foram testados azoxistrobina, cresoxim-metílico, piraclostrobina e trifloxistrobina, representando os fungicidas inibidores da quinona externa (IQe), bem como um inibidor da síntese da tubulina, o carbendazim e duas misturas prontas, trifloxistrobina + tebuconazole ou trifloxistrobina + protioconazol. Demonstrouse que os IDMs apresentaram as menores $\mathrm{CI}_{50}$ comparados com os IQes. Para os cinco isolados testados, na média geral, $\mathrm{a} \mathrm{CI}_{50}$ do crescimento micelial variou para os IDMs, de $0,01 \mathrm{mg} / \mathrm{L}$ (metconazol, procloraz e protioconazol) a 0,12 $\mathrm{mg} / \mathrm{L}$ (ciproconazol) e da germinação de conídios para os IQes de $0,21 \mathrm{mg} / \mathrm{L}$ (azoxistrobina) a $1,33 \mathrm{mg} / \mathrm{L}$ (trifloxistrobina). $\mathrm{ACI}_{50}$ para o carbendazim foi 0,07 $\mathrm{mg} / \mathrm{L}$. Todos os isolados testados podem ser considerados sensíveis aos IDMs estudados, embora algumas diferenças em sensibilidade tenham sido detectadas entre os isolados originados de um mesmo estado.

Palavras-chave adicionais: Fungitoxicidade, giberela, $\mathrm{CI}_{50}$, sensibilidade, Triticum aestivum.

Wheat (Triticum aestivum L.) is an important crop for food in Brazil. Its annual consumption is currently around 11 million tons, of which 6 million tons are produced and 5.6 million tons are imported. The amount of money spent on imports account for US\$ 933.9 millions (5).

Wheat production in Southern Brazil is a difficult task. The difficulties are directly related to excessive rain at the beginning of flowering up to crop ripening (15). Fungal diseases cause high damage to wheat production, particularly if their control is difficult, as is the case for fusarium head blight (FHB), caused by Gibberella zeae (Schw.)
Petch. (Anamorph Fusarium graminearum Schw.).

FHB was first described in the United States by Arthur (1891) and found in Brazil in 1942 in Veranópolis County, RS (7).

Casa \& Kuhnem Junior (4) reviewed the quantitative damage in Brazil from 1984 to 2010 growing seasons using a proper methodology. The mean damage during this period was $18.6 \%$ with a maximum of $39.8 \%$. Furthermore, in Brazil, ANVISA (2) recently issued 'Resolution-RDC No. 7', on February 18th, 2011, establishing a maximum permissible level for mycotoxins in wheat food (Brasil, 
2011). Thus, the pressure for rapid development of efficient FHB control measures has increased.

Although this disease has been known for a long time, there is no control measure that reduces the quantitative and qualitative damage to sub-economic levels in Brazil and worldwide. This is the greatest challenge for research. Thus, we must search for other immediate solutions for FHB management. In order to reduce losses caused by FHB on grain yield, some measures must be taken together.

In the attempt to obtain qualitative and quantitative economic control of FHB, it is fundamental to identify the most potent fungicide(s) to be used in field applications in order to control FHB.

The aim of this study was to determine the mycelial and spore germination sensitivity of Fusarium graminearum $(\mathrm{Fg})$ isolates to fungicides. Besides the characterization of intrinsic activities, the generated $\mathrm{IC}_{50}$ values also serve as a basis for the selection of the most potent fungicide in future field work.

\section{MATERIAL AND METHODS}

To evaluate the mycelial growth and conidial germination sensitivity of Fg to fungicides, the chemicals were incorporated in an agar medium, similarly to the method described by Russel (16). Five selected monosporic isolates were preserved in test tubes with PSA (potato sucrose agar) medium in a refrigerator at $5^{\circ} \mathrm{C}$ (Table 1 ) and used throughout this study.

Eight products containing carbendazim (Bendazol $500 \mathrm{SC}$ ), cyproconazole (Alto $100 \mathrm{SC}$ 100), epoxiconazole (Opus 125 SC) metconazole (Caramba 90 SL), tebuconazole (Folicur 200 EC), tebuconazole \& trifloxystrobin (Nativo 200 SC), trifloxystrobin + prothioconazole (Fox $175 \mathrm{SC}$ ), and prochloraz (Jade 450 EC) were assessed for mycelial growth inhibition. Additionally, azoxystrobin (Priori SC 250), kresoxim-methyl (Stroby 500 SC), pyraclostrobin (Comet $250 \mathrm{CE}$ ), trifloxystrobin (Twist $500 \mathrm{SC}$ ), trifloxystrobin + prothioconazole (Fox $175 \mathrm{SC}$ ), and tebuconazole + trifloxystrobin (Nativo 200 SC) were tested for conidial germination.

Seven-day-old colonies of each strain were grown on PSA (40 $\mathrm{g}$ potatoes, $10 \mathrm{~g}$ sucrose, $14 \mathrm{~g}$ agar in $1000 \mathrm{~mL}$ distilled water), supplemented with the fungicides after sterilization in an autoclave. Seven concentrations of each DMI fungicide were used as follows: 0, $0.01,0.10,1.00,10.00,20.00$ and $50.00 \mathrm{mg} / \mathrm{L}$, with four replicates. The day after the medium preparation, mycelial discs ( $6 \mathrm{~mm}$ diameter) of each isolate were placed upside down on the center of each Petri dish. The plates were sealed with PVC film and incubated in a growth chamber at $25 \pm 2^{\circ} \mathrm{C}$ and $12 \mathrm{~h}$ photoperiod for seven days.

Colony growth in two perpendicular diameters was measured with a digital caliper when the fungal growth in the control treatment had reached the plate edge. Means of the two diameters were used and converted to percent growth and compared with the fungal growth in the treatment of $0.00 \mathrm{mg} / \mathrm{L}$ (control). Logarithmical regression analysis using the statistical program Costat was performed. The inhibitory concentration $\left(\mathrm{IC}_{50}\right.$ ) capable of inhibiting $50 \%$ of $\mathrm{Fg}$ mycelial growth for each isolate and fungicide was calculated from the generated equation. The experimental design was a completely randomized factorial (fungicides $\mathrm{x}$ isolates), with four replicates, each experimental unit consisting of a Petri dish.

The experiments were repeated twice to ensure accuracy.

Surfaces of seven-day-old colonies grown in Petri dishes were scraped with a camel's hair brush number 20 , containing approximately $10 \mathrm{~mL}$ of sterile distilled water for conidial removal. On the day after medium preparation, $350 \mu \mathrm{L}$ of a conidial suspension were added to each Petri dish. The incubation was performed in a growth chamber at $25^{\circ} \mathrm{C}$ and $8 \mathrm{~h}$ continuous light. The germination was stopped by adding few drops of an acetone $(100 \mathrm{~mL})$ solution containing aniline $(1 \mathrm{~mL})$, which also stained the spores.

The percentage of germination was calculated on the basis of 100 conidia visually analyzed per Petri dish under an optical microscope, $400 \mathrm{x}$. Conidia were considered germinated if the germ tube length was equal to or greater than the smallest spore diameter (18). The germ tube was defined as short unbranched hyphae, which grew from the germ pore during germination (17). The experimental design was completely randomized with four replicates. Germination data of the five isolates for each active ingredient, calculated as percent of germination inhibition, were subjected to logarithmic regression analysis, using the statistical program Costat. The inhibitory concentration capable of inhibiting $50 \%\left(\mathrm{IC}_{50}\right)$ of spore germination for each isolate and fungicide was calculated by the generated equation.

The isolate sensitivity was classified according to the standard criteria of Edgington et al. (8), with the following attributes: insensitive when $\mathrm{IC}_{50}>50 \mathrm{mg} / \mathrm{L}$; moderately sensitive when $\mathrm{IC}_{50}$ between 1 and $10 \mathrm{mg} / \mathrm{L}$; highly sensitive when $\mathrm{IC}_{50}<1 \mathrm{mg} / \mathrm{L}$. The $\mathrm{IC}_{50}$ describe the active ingredient concentration, which inhibits $50 \%$ of the mycelial growth or of the spore germination.

\section{RESULTS AND DISCUSSION}

For cyproconazole, considering the means of two experiments, $\mathrm{IC}_{50}$ values of the mycelial growth inhibition test with the five isolates ranged from $<0.01$ to $0.47 \mathrm{mg} / \mathrm{L}$ and the coefficient of determination $\left(\mathrm{R}^{2}\right)$ from 0.93 to 0.99 (Fig. 1). Following the classification proposed by Edgington et al. (8), the isolates were considered sensitive to this fungicide. Analyzing the sensitivity of the isolates for carbendazim, the coefficient of determination $\left(\mathrm{R}^{2}\right)$ ranged from 0.86 to 0.93 and $\mathrm{IC}_{50}$ s from 0.02 to $0.14 \mathrm{mg} / \mathrm{L}$. The isolates were highly sensitive to this fungicide (Fig. 2). For epoxiconazole, $\mathrm{IC}_{50} \mathrm{~s}$ ranged from $<0.01$ to $0.09 \mathrm{mg} / \mathrm{L}$ and the coefficient of determination $\left(\mathrm{R}^{2}\right)$ from 0.89 to 0.98 (Fig. 3). The five isolates were as well sensitive to tebuconazole, with

Table 1. Identification of Fusarium graminearum monosporic isolates

\begin{tabular}{cccc}
\hline Isolate/code & State/county & Crop & Plant organ \\
\hline 01 & Paraná/Congoinhas & Corn & Stem \\
02 & Rio Grande do Sul/Passo Fundo & Wheat & Seed \\
03 & Rio Grande do Sul/Vacaria & Barley & Seed \\
04 & Paraná /Castro & Wheat & Seed \\
05 & Paraná/Cascavel & Wheat & Seed \\
\hline
\end{tabular}



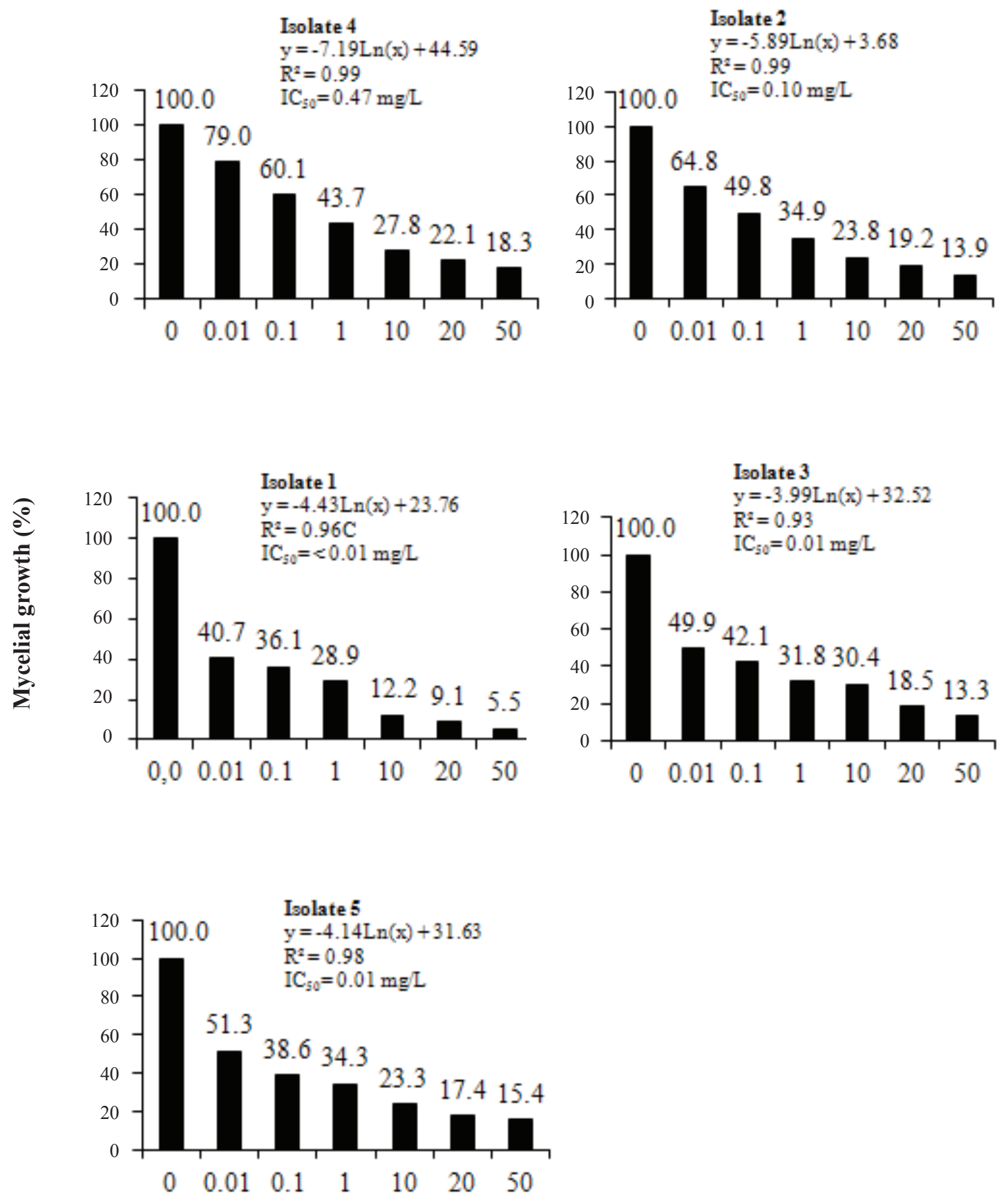

\section{Concentration $(\mathrm{mg} / \mathrm{L})$}

Figure 1. In vitro mycelial growth (\%) of Fusarium graminearum isolates, at seven concentrations $(\mathrm{mg} / \mathrm{L})$ of cyproconazole $(\mathrm{y}=$ mycelial growth $(\%)$ and $\mathrm{x}=$ fungicide concentration $\mathrm{mg} / \mathrm{L}$ active ingredient; $\mathrm{IC}_{50}=50 \%$ inhibitory concentration for mycelial growth). 

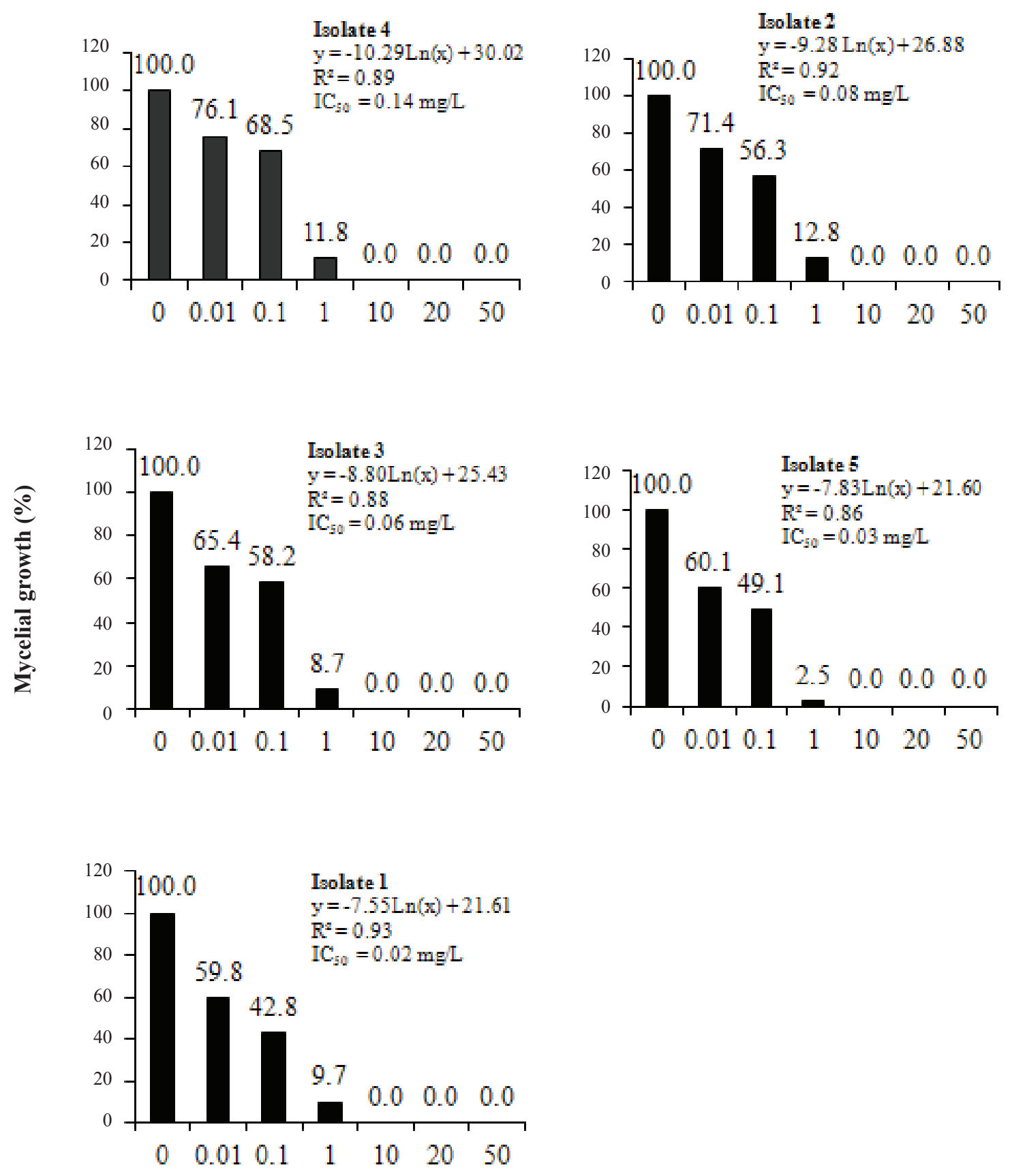

\section{Concentration $(\mathrm{mg} / \mathrm{L})$}

Figure 2. In vitro mycelial growth (\%) of Fusarium graminearum isolates, at seven concentrations $(\mathrm{mg} / \mathrm{L})$ of carbendazim $(\mathrm{y}=$ mycelial growth $(\%)$ and $\mathrm{x}=$ fungicide concentration $\mathrm{mg} / \mathrm{L}$ active ingredient; $\mathrm{IC}_{50}=50 \%$ inhibitory concentration for mycelial growth). 

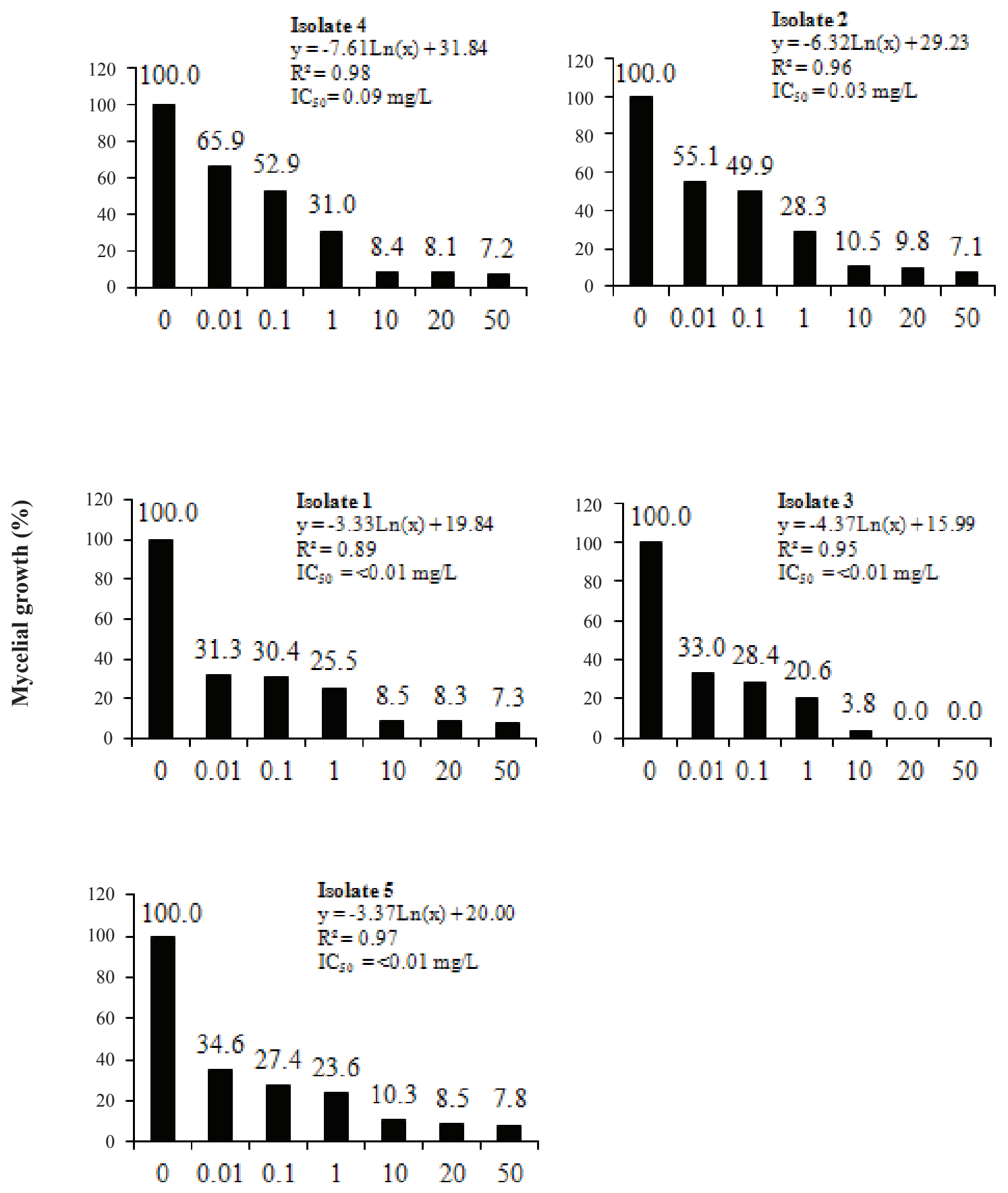

\section{Concentration (mg/L)}

Figure 3. In vitro mycelial growth $(\%)$ of Fusarium graminearum isolates, at seven concentrations $(\mathrm{mg} / \mathrm{L})$ of epoxiconazole $(\mathrm{y}=$ mycelial growth $(\%)$ and $\mathrm{x}=$ fungicide concentration $\mathrm{mg} / \mathrm{L}$ active ingredient; $\mathrm{IC}_{50}=50 \%$ inhibitory concentration for mycelial growth). 

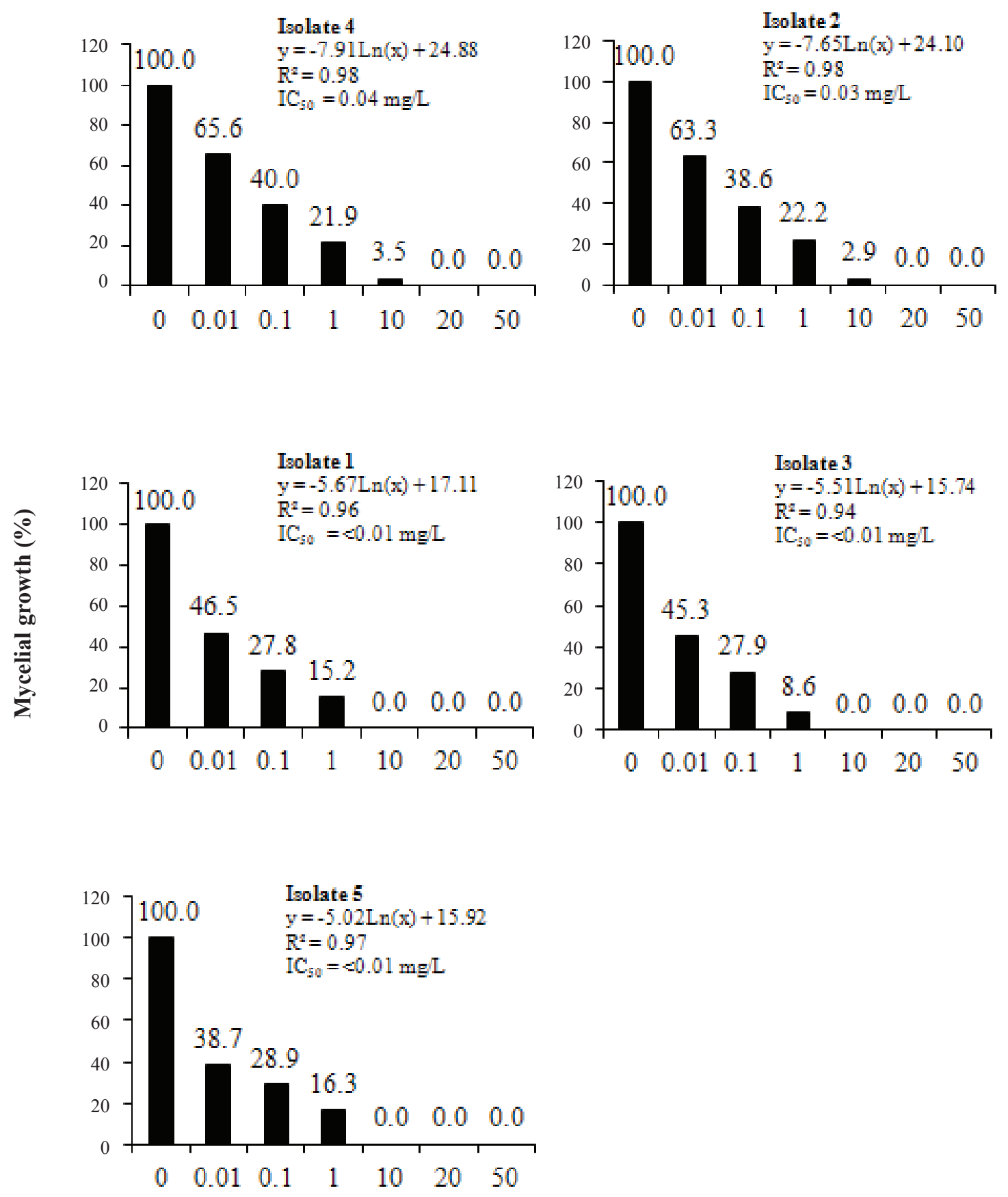

Concentration (mg/L)

Figure 4. In vitro mycelial growth (\%) of Fusarium graminearum isolates, at seven concentrations $(\mathrm{mg} / \mathrm{L})$ of tebuconazole $(\mathrm{y}=$ mycelial growth $(\%)$ and $\mathrm{x}=$ fungicide concentration $\mathrm{mg} / \mathrm{L}$ active ingredient; $\mathrm{IC}_{50}=50 \%$ inhibitory concentration for mycelial growth). 

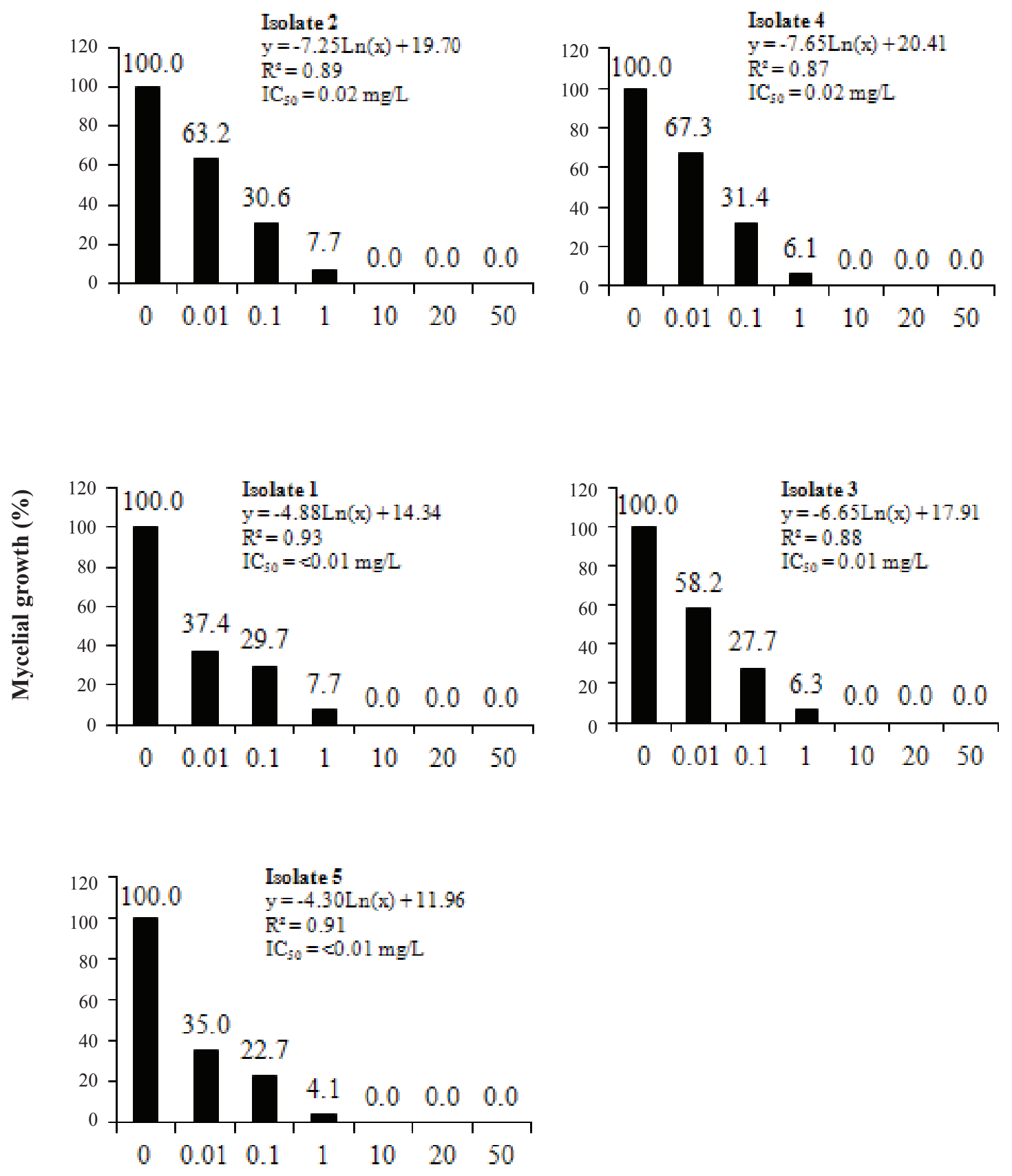

Concentration (mg/L)

Figure 5. In vitro mycelial growth (\%) of Fusarium graminearum isolates, at seven concentrations $(\mathrm{mg} / \mathrm{L})$ of prochloraz $(\mathrm{y}=$ mycelial growth $(\%)$ and $\mathrm{x}=$ fungicide concentration $\mathrm{mg} / \mathrm{L}$ active ingredient; $\mathrm{IC}_{50}=50 \%$ inhibitory concentration for mycelial growth). 

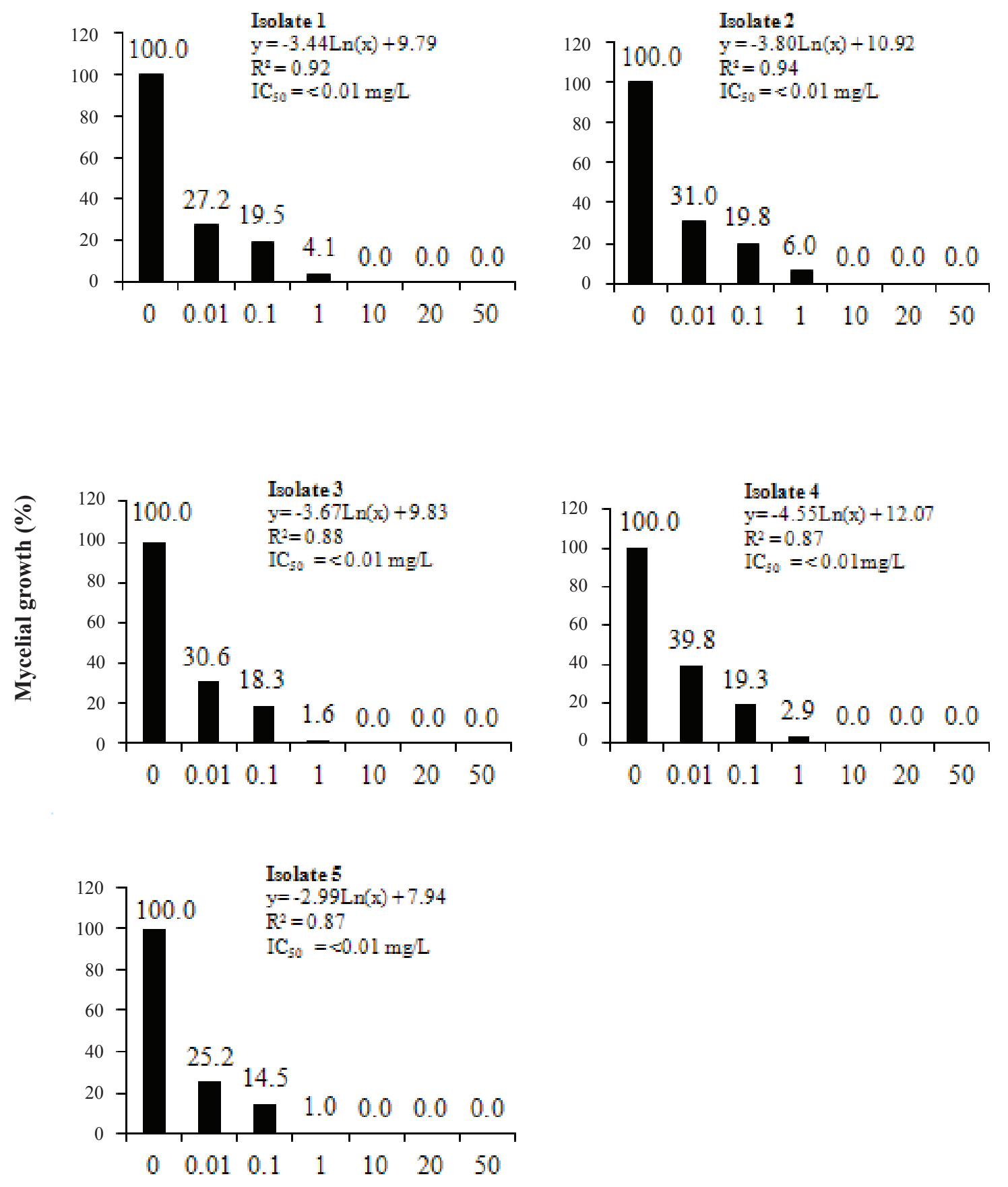

Concentration (mg/L)

Figure 6. In vitro mycelial growth (\%) of Fusarium graminearum isolates, at seven concentrations $(\mathrm{mg} / \mathrm{L})$ of metconazole $(\mathrm{y}=\mathrm{mycelial}$ growth $(\%)$ and $\mathrm{x}=$ fungicide concentration $\mathrm{mg} / \mathrm{L}$ active ingredient; $\mathrm{IC}_{50}=50 \%$ inhibitory concentration for mycelial growth). 

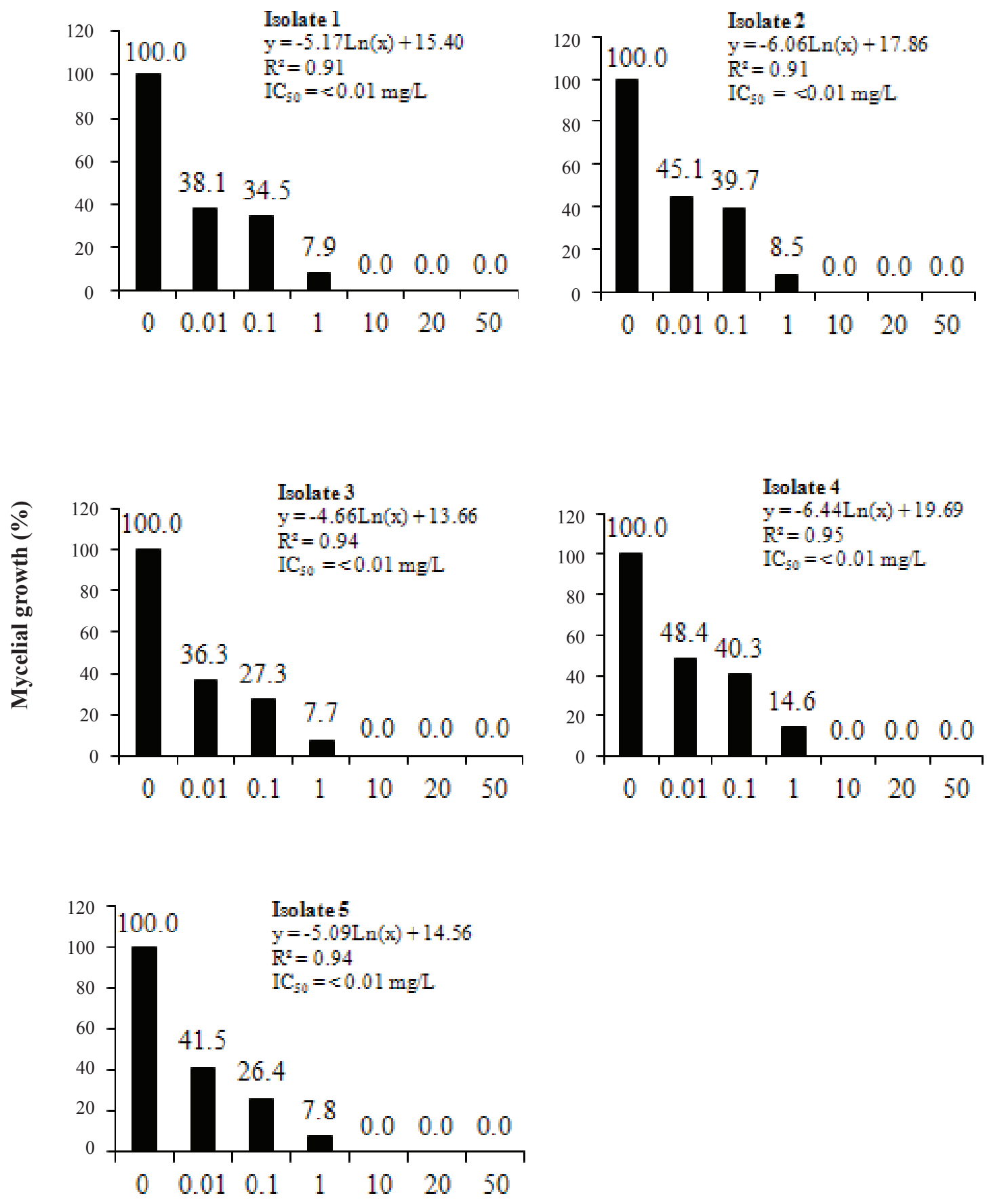

Concentration (mg/L)

Figure 7. In vitro mycelial growth (\%) of Fusarium graminearum isolates, at seven concentrations $(\mathrm{mg} / \mathrm{L})$ of trifloxystrobin + prothioconazole. $(\mathrm{y}=$ mycelial growth $(\%)$ and $\mathrm{x}=$ fungicide concentration $\mathrm{mg} / \mathrm{L}$ active ingredient; $\mathrm{IC}_{50}=50 \%$ inhibitory concentration for mycelial growth). 

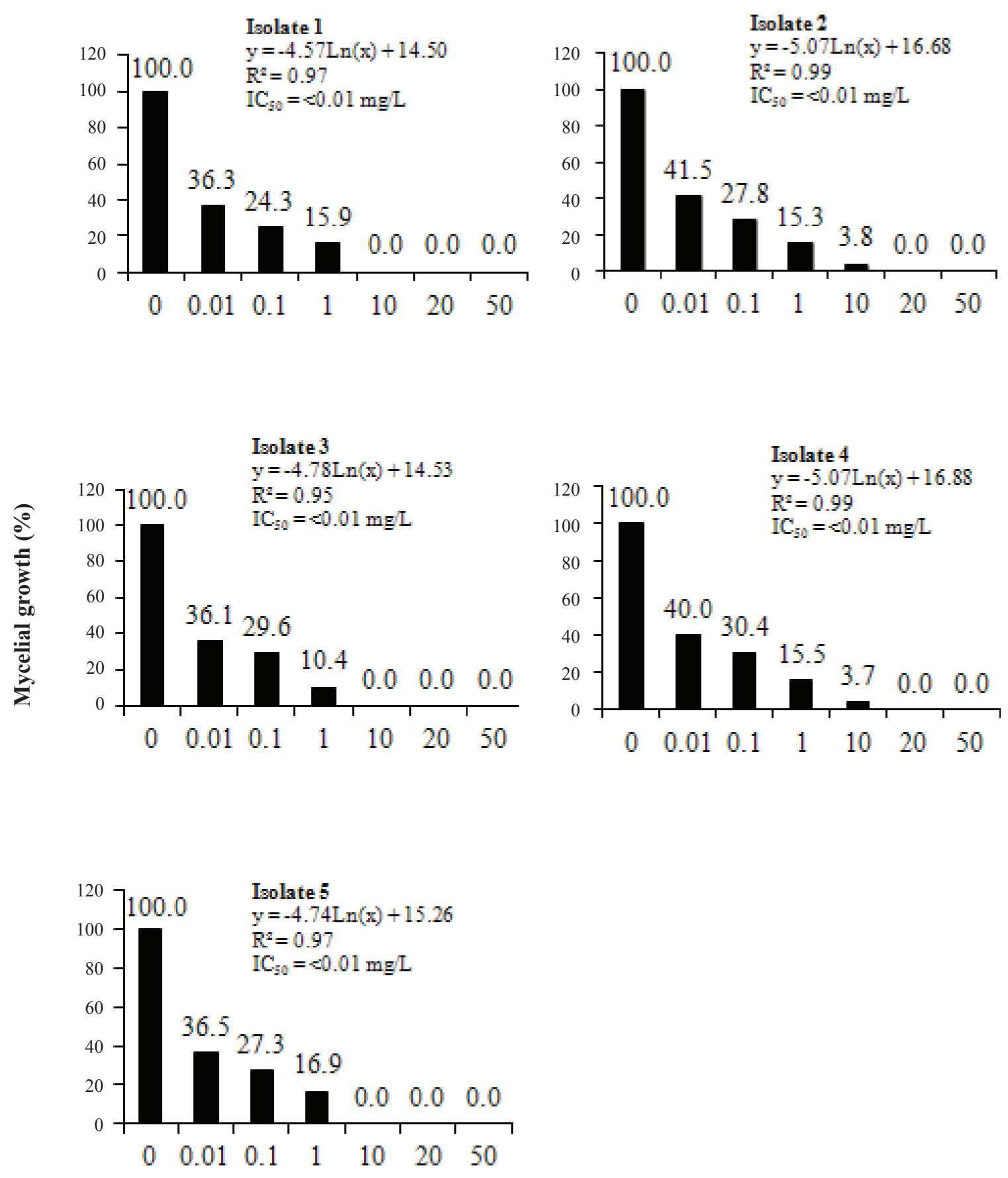

Concentration (mg/L)

Figure 8. In vitro mycelial growth (\%) of Fusarium graminearum isolates, at seven concentrations $(\mathrm{mg} / \mathrm{L})$ of trifloxystrobin + tebuconazole. $(\mathrm{y}=$ mycelial growth $(\%)$ and $\mathrm{x}=$ fungicide concentration $\mathrm{mg} / \mathrm{L}$ active ingredient; $\mathrm{IC}_{50}=50 \%$ inhibitory concentration for mycelial growth). 

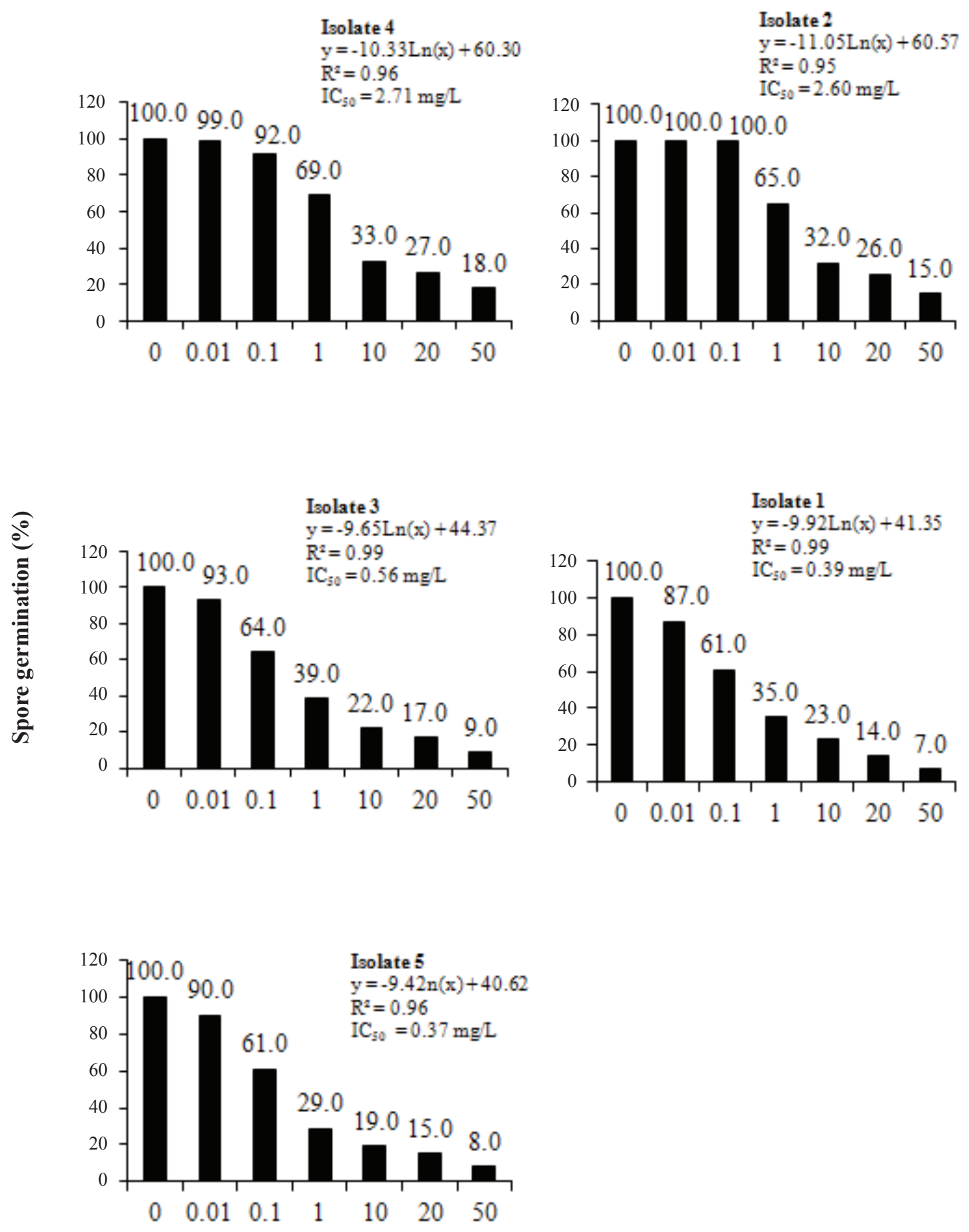

Concentration (mg/L)

Figure 9. In vitro spore germination (\%) of Fusarium graminearum isolates, at seven concentrations $(\mathrm{mg} / \mathrm{L})$ of trifloxystrobin $(\mathrm{y}=$ spore germination $(\%)$ and $\mathrm{x}=$ fungicide concentration $\mathrm{mg} / \mathrm{L}$ active ingredient; $\mathrm{IC}_{50}=50 \%$ inhibitory concentration for spore germination). 

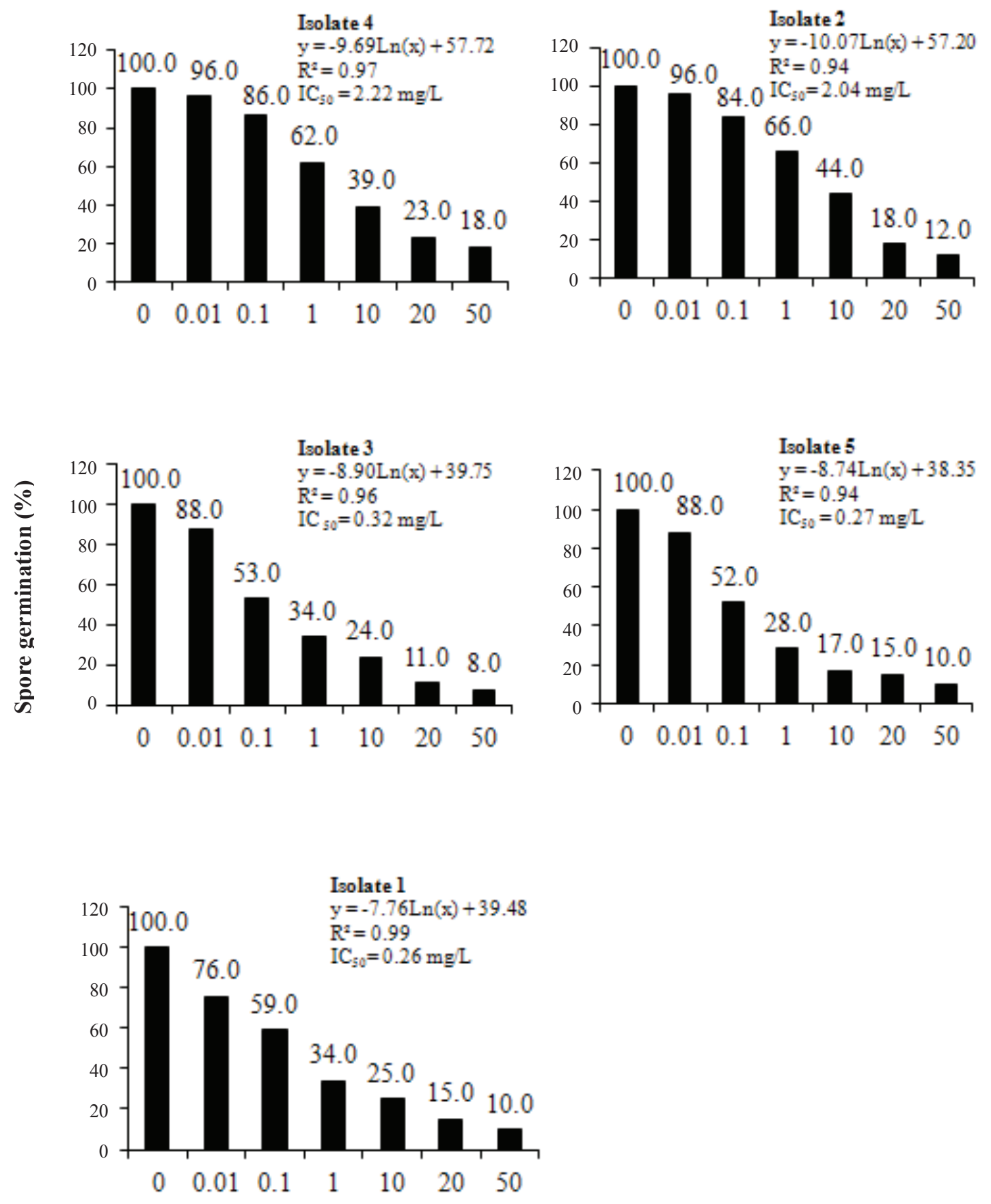

\section{Concentration $(\mathrm{mg} / \mathrm{L})$}

Figure 10. In vitro spore germination (\%) of Fusarium graminearum isolates, at seven concentrations $(\mathrm{mg} / \mathrm{L})$ of trifloxystrobin + tebuconazol $(\mathrm{y}=\mathrm{spore}$ germination $(\%)$ and $\mathrm{x}=$ fungicide concentration $\mathrm{mg} / \mathrm{L}$ active ingredient; $\mathrm{IC}_{50}=50 \%$ inhibitory concentration for spore germination). 

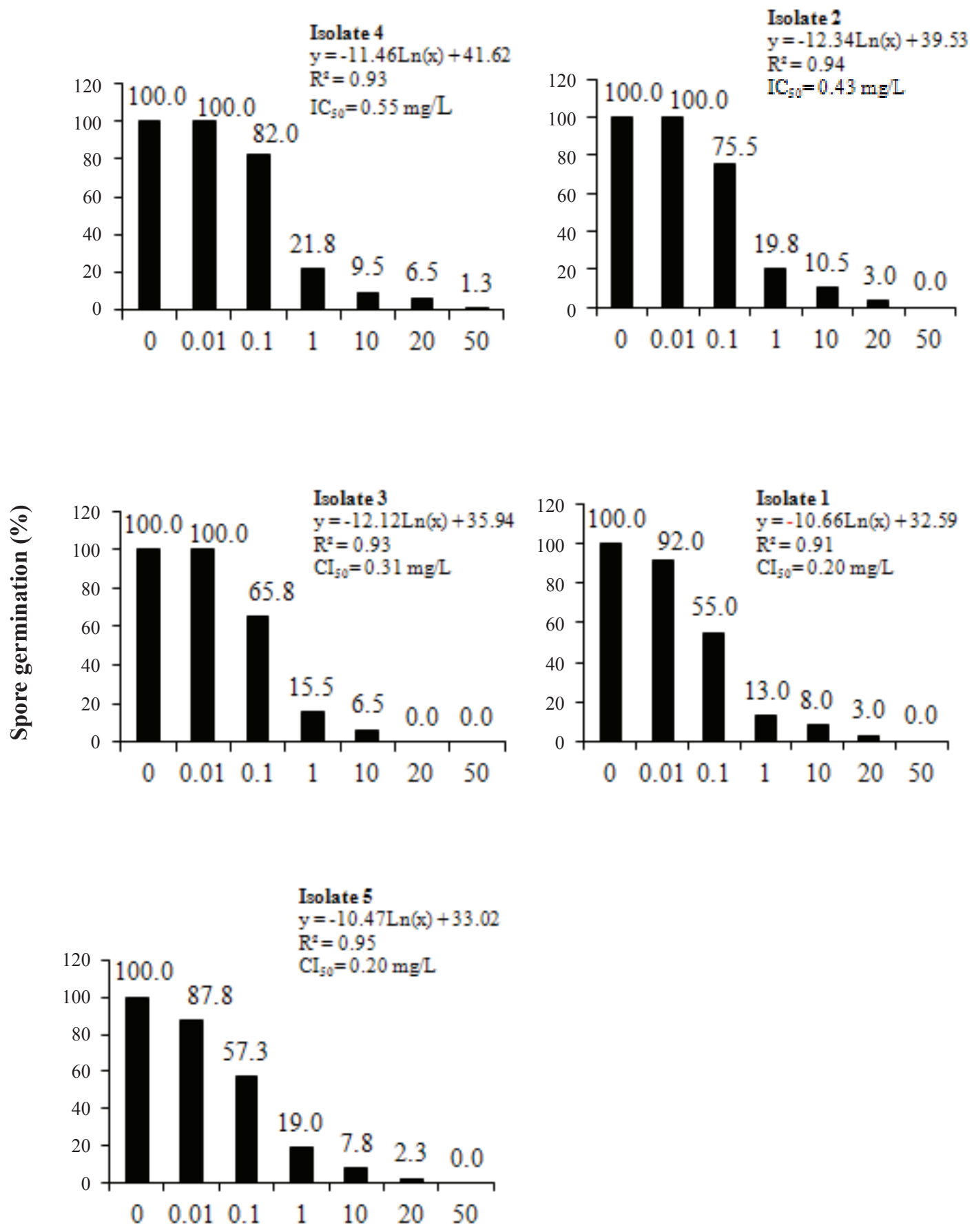

Concentration (mg/L)

Figure 11. In vitro spore germination (\%) of Fusarium graminearum isolates, at seven concentrations $(\mathrm{mg} / \mathrm{L})$ of pyraclostrobin $(\mathrm{y}=$ spore germination $(\%)$ and $\mathrm{x}$ $=$ fungicide concentration $\mathrm{mg} / \mathrm{L}$ active ingredient; $\mathrm{IC}_{50}=50 \%$ inhibitory concentration for spore germination). 

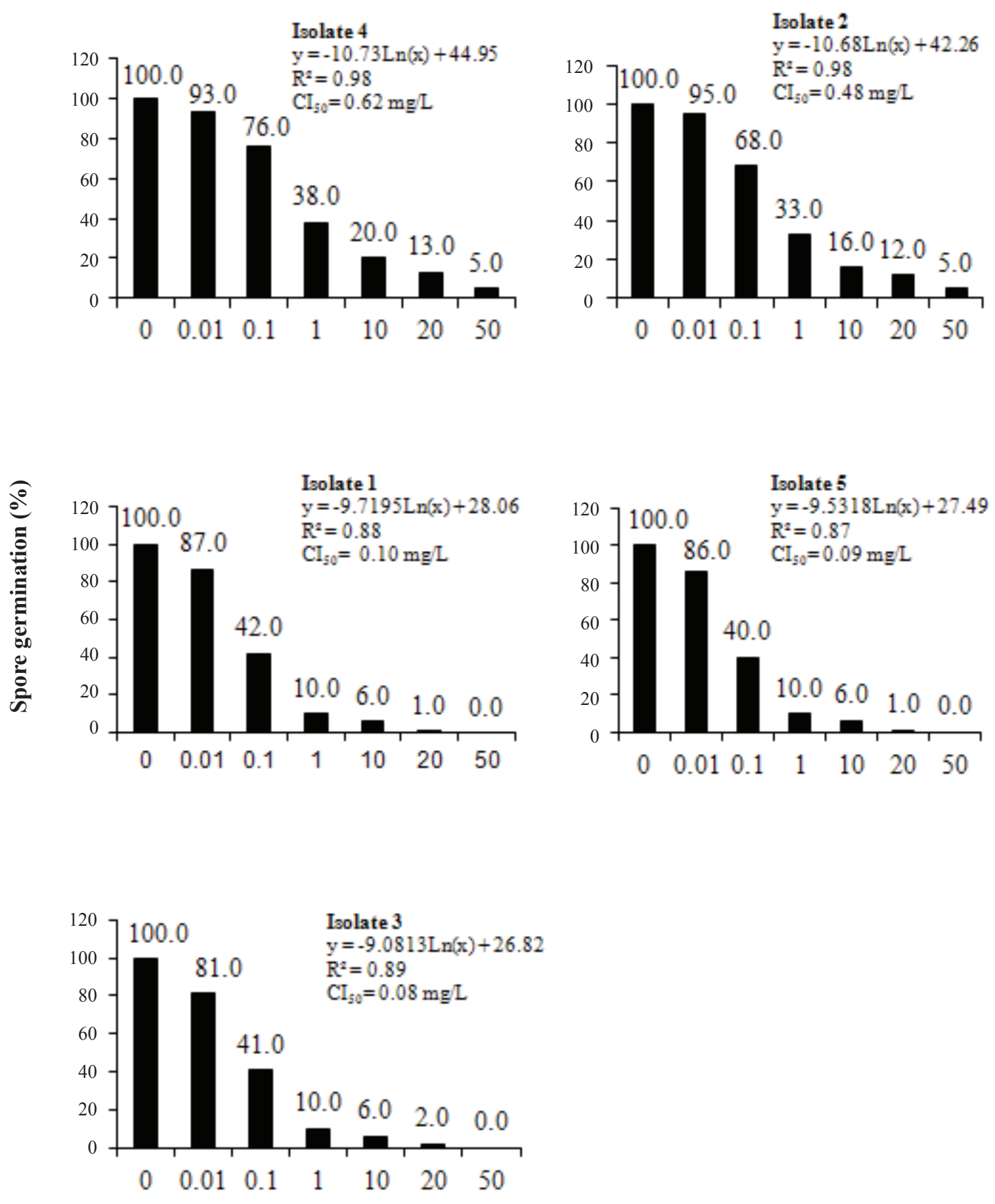

Concentration (mg/L)

Figure 12. In vitro spore germination (\%) of Fusarium graminearum isolates, at seven concentrations $(\mathrm{mg} / \mathrm{L})$ of kresoxim-methyl $(\mathrm{y}=$ spore germination $(\%)$ and $\mathrm{x}=$ fungicide concentration $\mathrm{mg} / \mathrm{L}$ active ingredient; $\mathrm{IC}_{50}=50 \%$ inhibitory concentration for spore germination). 

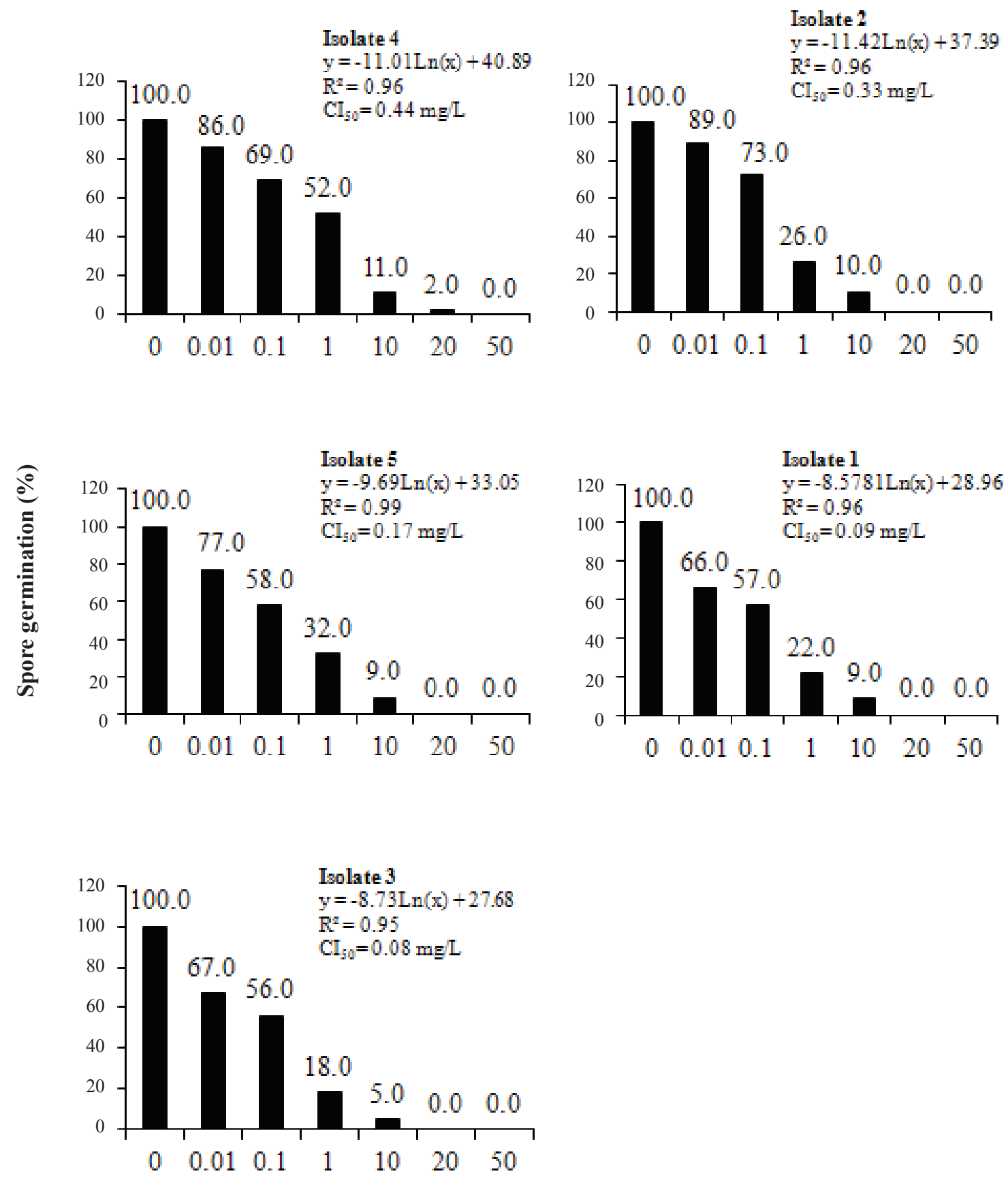

Concentration (mg/L)

Figure 13. In vitro spore germination (\%) of Fusarium graminearum isolates, at seven concentrations $(\mathrm{mg} / \mathrm{L})$ of trifloxystrobin + prothioconazole. $(\mathrm{y}=$ spore germination (\%) and $\mathrm{x}=$ fungicide concentration $\mathrm{mg} / \mathrm{L}$ active ingredient; $\mathrm{IC}_{50}=50 \%$ inhibitory concentration for spore germination). 

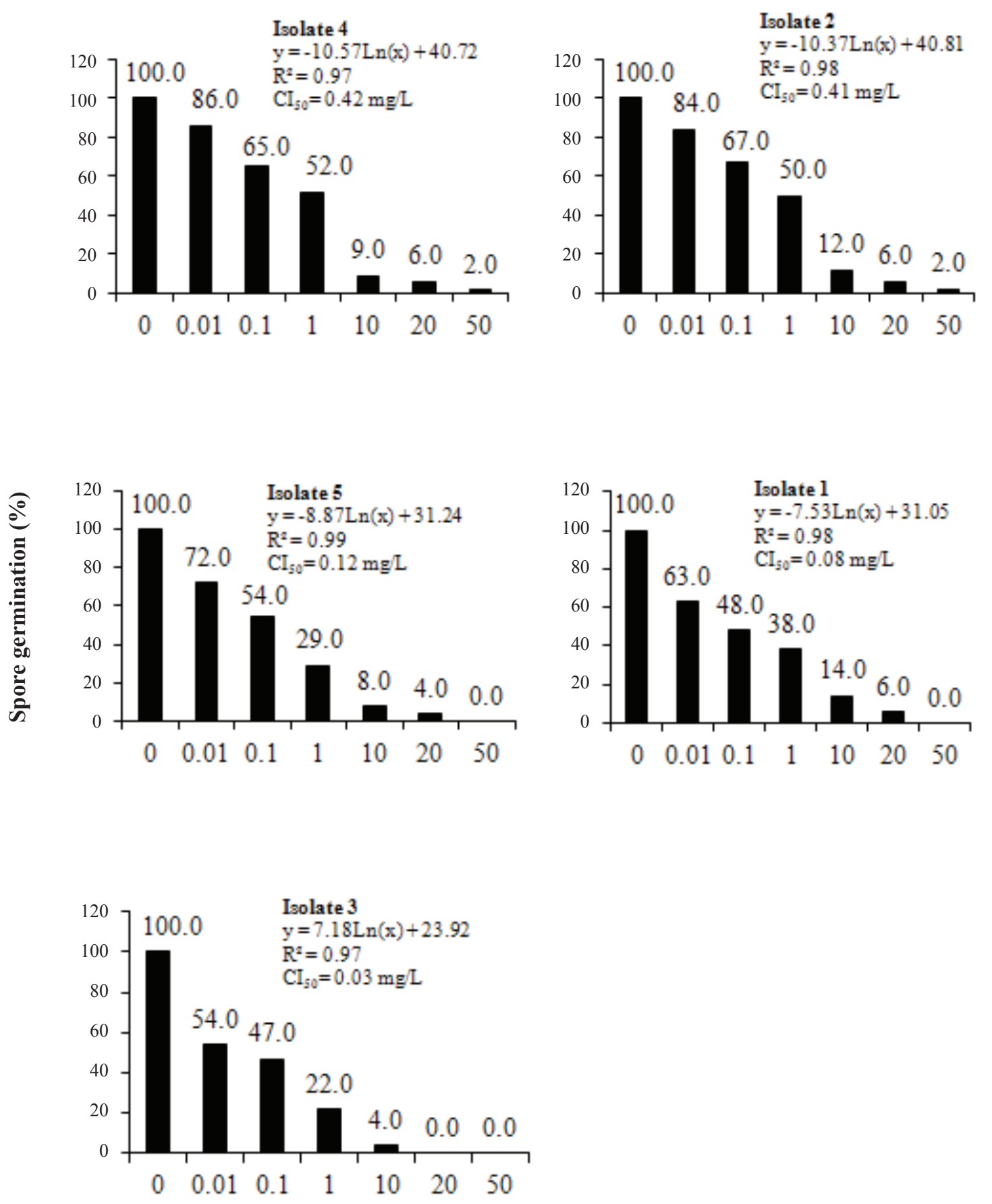

Concentration $(\mathrm{mg} / \mathrm{L})$

Figure 14. In vitro spore germination ( $\%)$ of Fusarium graminearum isolates, at seven concentrations $(\mathrm{mg} / \mathrm{L})$ of azoxystrobin $(\mathrm{y}=\mathrm{spore}$ germination $(\%)$ and $\mathrm{x}=$ fungicide concentration $\mathrm{mg} / \mathrm{L}$ active ingredient; $\mathrm{IC}_{50}=50 \%$ inhibitory concentration for spore germination). 
$\mathrm{IC}_{50}$ values of $<0.01$ to $0.04 \mathrm{mg} / \mathrm{L}$ and coefficients of determination $\left(\mathrm{R}^{2}\right)$ from 0.94 to 0.98 (Fig. 4). Prochloraz: the mycelial growth of all studied strains was completely inhibited at $10 \mathrm{mg} / \mathrm{L}$. $\mathrm{IC}_{50} \mathrm{~s}$ ranged from $<0.01$ to $0.02 \mathrm{mg} / \mathrm{L}$ and the coefficient of determination $\left(\mathrm{R}^{2}\right)$ from 0.87 to 0.93 , respectively (Fig. 5). Again, according to Edgington

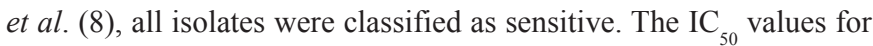
metconazole were $<0.01 \mathrm{mg} / \mathrm{L}$ for the five isolates, and the coefficient of determination $\left(\mathrm{R}^{2}\right)$ ranged from 0.87 to 0.94 (Fig. 6). $\mathrm{IC}_{50} \mathrm{~s}$ for prothioconazole \& trifloxystrobin (Fig. 7) were $<0.01 \mathrm{mg} / \mathrm{L}$, coefficient of determination $\left(\mathrm{R}^{2}\right)$ between 0.91 to 0.95 , and at $10 \mathrm{mg} / \mathrm{L}$ mycelium growth inhibition was $100 \%$. For tebuconazole \& trifloxystrobin, $\mathrm{IC}_{50}$ values were as well $<0.01 \mathrm{mg} / \mathrm{L}$ and the coefficient of determination $\left(\mathrm{R}^{2}\right)$ ranged from 0.95 to 0.99 for the five isolates (Fig. 8).

The DMI's epoxiconazole, metconazole, prothioconazole and tebuconazole and prochloraz were most potent, providing increased efficiency in the mycelium growth inhibition, with $\mathrm{IC}_{50}<0.01 \mathrm{mg} / \mathrm{L}$. All tested fungicides showed fungitoxicity for mycelium growth with $\mathrm{IC}_{50} 0.01 \mathrm{mg} / \mathrm{L}$ for all isolates. Nevertheless, the isolates showed, as expected, different sensitivity to the fungicides; isolates 02 and 04 were the least sensitive ones. Mesterházy (13) also reported the high fungitoxicity of metconazole, prothioconazole and tebuconazole to $\mathrm{Fg}$, which is in agreement with our data.

Regarding spore germination, $\mathrm{IC}_{50}$ values $>1.0 \mathrm{mg} / \mathrm{L}$ were determined for both isolates 02 and 04 , with $\mathrm{IC}_{50} \mathrm{~s}$ of 2.60 and $2.71 \mathrm{mg} / \mathrm{L}$ for trifloxystrobin. Those isolates were moderately sensitive to these active ingredients (Figs. 9 and 10). The $\mathrm{IC}_{50}$ values for the five isolates, considering pyraclostrobin, kresoxym methyl and azoxystrobin, ranged from 0.03 to $0.62 \mathrm{mg} / \mathrm{L}$ (Figs. 11, 12 and 14). According to the classification proposed by Edgington et al. $(8,9)$, the five isolates were considered sensitive, showing $\mathrm{IC}_{50}<1.0 \mathrm{mg} / \mathrm{L}$. Isolate 03 was most sensitive to QoI (Fig. 11, 12, 14) with an $\mathrm{IC}_{50}$ of $0.03 \mathrm{mg} / \mathrm{L}$ to 0.08 .

Azoxystrobin was the most potent fungicide to inhibit spore germination, showing the lowest $\mathrm{IC}_{50}$ values for the five isolates.

In 1929, Christensen et al. (6) said that "the only effective method to controlling wheat scab is to grow resistant varieties". Later McMullen et al. $(11,12)$ emphasized that "crop rotations are the key to reducing risk of severe scab". Nevertheless, the effectiveness of crop rotations in reducing scab has not been demonstrated in Brazil. Likewise, in Argentina, Moschini et al. (14) suggested that favorable weather conditions are likely to be more important than tillage practice in disease severity. Thus, FHB is a disease difficult to manage, and under environmental conditions favorable to the pathogen, the use of just a single management strategy may result in management failure.

Not much has changed since then. The alternative is that resistance will be discarded when environmental conditions become unfavorable for scab. Therefore, while resistant cultivars are not available, a more feasible alternative for FHB control is to improve the efficiency of chemical control. Thus, epoxiconazole, metconazole, prothioconazole and tebuconazole showed the highest fungitoxicity for use in FHB control. However, fungicide deposition should be improved to reach and cover the partially exserted anthers, the infection sites (3). Therefore, it is not sufficient to have only a high fungitoxic fungicide if the spraying equipment is not efficient enough to completely cover the infection sites located at the head sides.

\section{REFERENCES}

1. Arthur J. C. Wheat Scab. Agricultural Experimental Station, Minnesota v. 36, p.192-232, 1981.

2. Brasil (2011) Regulamento técnico sobre limites máximos tolerados (LMT) para micotoxinas em alimentos. Resolução $R D C n^{\circ} 7$, de 18 de fevereiro de 2011. Brasília, DF: ANVISA, 2011.

3. Brustolin, R.; Reis, E. M.; Boller, W.(2011) Tecnologia de aplicação de fungicidas. In: Reis EM (Org.) Seminário sobre giberela em cereais de inverno. Passo Fundo, Berthier, 2011p. 253-264. Coletânea de trabalhos.

4. Casa, R. T.; Kuhnem, Junior, P. R. Danos causados nos hospedeiros. In: Reis E. M. (Org.) Seminário sobre giberela em cereais de inverno. Passo Fundo, Berthier, Passo Fundo. p.73-86, 2011. Coletânea de trabalhos

5. Companhia Nacional de Abastecimento. Brasília, 2014. Acompanhamento da safra brasileira: trigo: safra 2011/2012: quinto levantamento. Disponível em < http://www.cnpt.embrapa.br/obs_trigo/conab/levantamento $\% 20$ Conab-fev-2011.pdf $>$ Acesso em 29 de junho de 2012.

6. Christensen, J. J.; Stakman, E.C. and Immer, F. R. Suseptibility of wheat varietis and hybrids to fusarium head blight in Minnesota. Minnesota Agriy cultural Expeerimentalk Station,. Bulletin St. Paul, v. 59, 1929.

7. Costa Neto, J. P. Parasitas de plantas cultivadas no Rio Grande do Sul. Porto Alegre: Secretaria de Estado dos Negócios da Agricultura, Indústria e Comércio, 1947. 21p.

8. Edgington, L. V.; Khew, K. L.; Barrow, G. L. Fungitoxic spectrum of benzimidazole compounds. Phytopathology, St. Paul, v. 61, p. 42- 44, 1971.

9. Edgington, L. V.; Martin, R. A.; Bruin, G. C.; Parsons, I. M. Systemic fungicides: A perspective after 10 Years. Plant Disease, St. Pau, vol. 64, n. 1, p. 19-23, 1980 .

10. Ghini R, Kimati H. Resistência de fungos a fungicidas. Jaguariúna: Embrapa Meio Ambiente, 2000, 78 p.

11. McMullen M, Jones R, Gallenberg D (1997) Scab of wheat and barley: a re-emerging disease of devastating impact. Plant Disease, St. Paul, v.81, n. 12 , p. $1340-1348,1997$

12. McMullen M, Gary Bergstrom G, De Wolf E, Dill-Macky Hershman R.D, Greg Shaner G , Dave Van Sanford D (2012) A unified effort to fight an enemy of wheat and barley: fusarium head blight. Plant Disease, St Paul. (in press).

13. Mesterházy, A. Control of Fusarium head blight of wheat by fungicides. In: Leonard, K.J., Bushnell, W.R. (Eds.) Fusarium Head Blight of Wheat and Barley. The American Phytopathological Society: St. Paul, USA, 2003, Chap.13,pp.363-80, 2003.

14. Moschini, R.; Pioli, R.; Carmona, M.;Sacchi, O. Empirical predictions of wheat head blight in the Northern Argentinean pampas region. Crop Science, Madison, v. 41, p. 1541- 1545, 2001.

15. Reis, E. M.; Blum, M. M. C.; Casa, R. T.; Medeiros, C. A. Grain losses caused by infection of wheat heads by Gibberella zeae in southern Brazil, from 1984 to 1994. Summa Phytopathologica, Botucatu, v. 22, p. 134-137, 1996.

16. Russel, P. E. Sensitivity baselines in fungicide resistance research and management. Cambridge, 2004.

17. Ulloa, M,; Hanlin, R. T. Ilustrated dictionary of mycology. St. Paul: The American Phytopathological Society, 2000, 448 p.

18. Zadocks, J. C.; Schein, R. Epidemiology and plant disease management. New York: Oxford University Press, 1979. 427 p. 